Michat Mordań

Uniwersytet w Białymstoku

Wydział Filologiczny

Katedra Językoznawstwa Porównawczego i Stosowanego

tel. +48857457450

e-mail:m.mordan@uwb.edu.pl

ORCID ID: https://orcid.org/0000-0002-5709-3469

\title{
Nazwy zawodów, godności i urzędów jako podstawy motywacyjne współczesnych nazwisk Podlasian
}

Słowa kluczowe: językoznawstwo, onomastyka, antroponimia, nazwiska, nazwy odzawodowe

I. Antroponimy motywowane nazwami zawodów, godności i urzędów nie stanowią na ogół odrębnej grupy w klasyfikacjach nazwisk. Zazwyczaj są one omawiane łącznie z innymi formami odapelatywnymi reprezentującymi tzw. typ przezwiskowy [Rudnicka-Fira 2003, 205; Rudnicka-Fira 2004, 153-154; Kuć 2004, 103-104; Dacewicz 2014, 140-156] ${ }^{1}$. Zdaniem Józefa Bubaka [1986, 156], takie rozwiązanie może być dyskusyjne z perspektywy procesu formowania się nazwiska jako kategorii antroponimicznej. Określenia pochodzące od nazw profesji i godności mówią o realnym zawodzie wykonywanym przez człowieka, wskazują na jego status i pełnione funkcje. Odznaczają się zatem neutralnym ładunkiem emocjonalnym, brakiem przezwiskowości i ekspresji, towarzyszącej zazwyczaj formom odapelatywnym w momencie ich powstawania.

\footnotetext{
1 Na wstępie należy zwrócić uwagę, że sam termin nazwiska odzawodowe jest określeniem stosunkowo pojemnym. Obejmuje on nie tylko antroponimy motywowane stricte nazwami zawodów (w znaczeniu: 'fachowe, stałe wykonywanie jakiejś pracy w danej dziedzinie; fach, specjalność' SJPDor X 880-881), ale również nazwiska od określeń urzędów, godności, pełnionych funkcji, a nawet od nazw wskazujących na status społeczny i ekonomiczny osoby identyfikowanej [Rudnicka-Fira 2003, 205; por. Biryła 1966, 191-193].
} 
Aleksandra Cieślikowa [1990, 203], analizując staropolskie antroponimy odapelatywne stwierdza, że jedynie część spośród nazw osobowych równych określeniom zawodów „powstała jako deskrypcje określone niezupełne, niosące treści odpowiadające rzeczywistości pozajęzykowej". Natomiast antroponimy, w przypadku których zgodność pola antroponimicznego z polem semantycznym nie jest potwierdzona, są motywowane przez znaczenia metaforyczne apelatywu. Charakter przenośny, niekiedy także ironiczny mogły mieć na przykład nazwiska od nazw osób duchownych, od tytułów wysokich urzędów państwowych, zwłaszcza obcych kulturze lokalnej [por. np. Lech 2003, 221]. W podobny sposób wypowiada się Zofia Kaleta [1998, 49-50], która umieszcza nazwiska od nazw zawodów, wykonawców czynności, urzędów, godności i stanowisk w zbiorze odapelatywnych, jednocześnie zaliczając je do grupy nazw osobowych metaforycznych. Tylko nieliczne nazwy można zakwalifikować, z dużym prawdopodobieństwem, jako określenia użyte przenośnie, metaforycznie, nacechowane ekspresywnie (por. np. Biskup, Car, Król, Papież) [zob. Rudnicka-Fira 2004, 153-154]. Semantyka podstawy derywacyjnej takiej nazwy wyklucza możliwość jej użycia w funkcji określenia odpowiadającego rzeczywistości. Zdaniem Kazimierza Rymuta, w epoce średniowiecza nazwy osobowe równe apelatywom określającym zawód znajdowały się na pograniczu między kategoriami nomen proprium i nomen apellativum ${ }^{2}$. Mieszcząc się w strefie przejściowej mogły jednocześnie znaczyć i oznaczać [por. Rymut 1982, 335-339]. Dopiero w wiekach późniejszych traciły swą pierwotną funkcję realnoznaczeniową stając się nazwiskami [Rudnicka-Fira 2004, 154]. Na Podlasiu w XVI w. ta grupa określeń znajdowała się jeszcze na pograniczu nazw własnych i wyrazów pospolitych, ale z badań Lilii Citko [2001, 90] wynika, że relacja semantyczna między nazwą odzawodową identyfikującą osobę a realnie wykonywanym przez nią zawodem była utrzymana ${ }^{3}$.

Problem klasyfikacyjny nazwisk motywowanych nazwami profesji, urzędów, godności i funkcji wynika również z odmiennego podejścia badaczy ${ }^{4}$ do samych określeń, traktowanych bądź w charakterze jednej z grup zna-

2 Por. też termin apelatyw onimiczny wprowadzony przez Kazimierza Rymuta [1987, 319] oraz stanowisko Aleksandry Cieślikowej [1990, 201] w kwestii jego definicji.

3 Na terenie Podlasia w XVI wieku nazwy te w znacznej liczbie były mianami o charakterze apelatywnym, w związku z czym należałoby wyodrębnić tę grupę określeń identyfikujących jako nazw reprezentujących „niezupełnie jeszcze zantroponimizowany model nazewniczy" [Citko, Dacewicz 1996, 87].

4 Aleksandra Cieślikowa przytacza prace Stanisława Rosponda, Henryka Borka, Sławomira Gali, Zofii Kalety, Aleksandry Cieślikowej, Józefa Bubaka i in. dotyczące klasyfikacji nazwisk i w niektórych przypadkach przeniesień do antroponimów [zob. Cieślikowa 1990, 151-152; tamże cytowana literatura]. 
czeniowych wyrazów pospolitych, bądź postawionych w opozycji do innych apelatywów [por. Cieślikowa 1990, 152].

Identyfikacja osoby poprzez wskazanie na wykonywane rzemiosło lub piastowany urząd miała w Polsce miejsce już w XII-XIII w., a w wiekach następnych ten sposób nominacji występuje coraz częściej [Dacewicz 1993, 94; Kuć 2004, 104]. Wschodnie tereny dzisiejszej Polski były w przeszłości uboższe pod względem frekwencji i różnorodności nazw zawodów, stanowisk i godności w porównaniu z innymi regionami, np. Śląskiem czy Wielkopolską. Przyczyn takiego stanu rzeczy należy upatrywać w sytuacji gospodarczej i kulturowej [por. Wolnicz-Pawłowska, Szulowska 1998, 201-208]. Liczba kupców, rzemieślników różnych specjalności oraz osób piastujących rozmaite funkcje społeczne w dużym stopniu zależała od poziomu urbanizacji [por. Rudnicka-Fira 2004, 155-156]. Na obszarze Podlasia współczesnego zasób nazwisk reprezentujących omawiany model antroponimiczny jest stosunkowo liczny, co potwierdza cytowany niżej materiał źródłowy. Na tę różnicę między materiałem historycznym i współczesnym, przede wszystkim pod względem ilościowym, miały wpływ procesy historyczno-społeczne i towarzyszące im ruchy migracyjne, którymi obfitowały ostatnie stulecia.

II. Bazą źródłową niniejszego artykułu są współczesne nazwiska mieszkańców trzech miast na pograniczu polsko-białoruskim: Bielska Podlaskiego, Hajnówki i Siemiatycz. Antroponimy te można podzielić na kilkanaście podzbiorów, w zależności od semantyki podstawy motywującej. Uwzględniając aspekt strukturalny, w zebranym materiale zaznaczają się dwa główne modele. Pierwszy zbiór obejmuje nazwiska będące przeniesieniami określeń zawodów, godności i pełnionych funkcji. W niektórych przypadkach onimizacji towarzyszy adaptacja fonetyczno-graficzna nazw niesłowiańskich (niemieckich, rzadziej litewskich). Drugą grupę reprezentują nazwiska derywowane sufiksalnie. Niektóre przyrostki uczestniczące w ich kreacji należą do formantów patronimicznych (-owicz, -ewicz, a także -uk/-czuk) lub dzierżawczych $(-o w,-e w)$, inne mogły tworzyć derywaty w płaszczyźnie apelatywnej (np. -un, -yło itp.). Część wykorzystanych sufiksów to formanty polifunkcyjne $\left(-a k^{5},-e k,-i k,-k o\right.$ i in.) [por. Bubak 1986, 73-74]. Proces tworzenia antroponimów derywowanych mógł zatem zachodzić zarówno w planie apelatywnym, jak i antroponimicznym [por. Rudnicka-Fira 2004, 157-159]. Do podstaw słowotwórczych zawierających nazwy profesji i urzędów mógł być również dołączany sufiks -ski, tworząc w ten sposób tzw. nazwiska

$5 \mathrm{Na}$ patronimiczną funkcję przyrostka $-a k /$ 'ak w nazwach odzawodowych wskazuje Joanna Kuć [2004, 107]. 
modelowe, nobilitujące, np. Włodarski, Piwowarski ${ }^{6}$ [Rudnicka-Fira 2003, 207-208; Rudnicka-Fira 2004, 155].

1. Najwyższą frekwencją wykazują się nazwy rzemieślników różnych specjalności: Bednarz < bednarz 'rzemieślnik, wyrabiający naczynia klepkowe' SW I 110; Bondar < wschsł. gw. bondar, ros. bondar' 'bednarz'7 SGPRei II 375, AGWB I 101, Gr-Med 62; Cieśla < cieśla 'rzemieślnik wykonujący prace ciesielskie' SW I 333; Dojlida < lit. dailide 'cieśla' LauSB 36, LLKŻ 79, LPŻ I 445; Dudnik < ros. dudnik 'ten, kto wytwarza piszczalki'8 Ganż 175; Dykiert < niem. Decker < Dachdecker 'dekarz' $(+t$; por. nazw. Dykier, Dykier(ek)) Lex I 152; Golnik < może ros. igol'nik 'rzemieślnik wyrabiający igły do szycia'9; Koleśnik < koleśnik 'kołodziej, stelmach' SW II 401; Kołodziej < kołodziej 'stelmach, rzemieślnik robiący koła do wozów' SW II 411; Koszewnik < może *koszewnik < ros. koszewa 'pot. szerokie sanie z wysoką częścią tylną, obite wojłokiem z owczej lub wielbłądziej wełny' - być może osoba, wyrabiająca takie sanie BTS 46410; Krawiec < krawiec 'rzemieślnik robiący ubrania' SW II 534; Kuśmierz < gw. kuśmierz 'kuśnierz' SW II 651; Palacz < palacz 'ten, co pali w piecu i podtrzymuje ogien, sularz' SW IV 14; Płóciennik, Płuciennik < płóciennik 'tkacz wyrabiający płótno' SW IV 266; Rezler < wschśrniem. reseler 'szewc' SENiem 206; Sitarz < sitarz 'ten, co wyrabia sita' SW VI 120; Sitnik < ros. sitnik 'rzemieślnik wyrabiający sita' Ganż 434; Skrzyniarz < skrzyniarz 'ten, co robi skrzynie' SW VI 191; Stelmach < stelmach 'rzemieślnik wyrabiający drewniane korpusy i części powozów i bryczek, kołodziej' SW VI 668; Sudnik $<$ ros. sudnik 'ten, kto wytwarza naczynia drewniane'11 Ganż 458; Surmacz $<$ pol., brus. surmacz 'ten, co robi surmy' SW VI 516, TSBM V/1 390;

6 W niniejszym opracowaniu uwzględniono nazwiska na -ski, dla których nie znaleziono nazw miejscowych, mogących stanowić domniemaną podstawę fundującą.

7 Na temat ap. bednarz, bondar zob. Rymut 1987, 321.

8 Joanna Kuć $[2004,110]$ rozpatruje n.os. Dudnik jako nieposiadająca apelatywnego poświadczenia słownikowego i wiąże ją z ap. dudnić 'wydawać głuchy przytłumiony odgłos, grać mocno i uporczywie, bębnić' (objaśnienie wg SW).

9 Por. nazw. ros. Igol'nik [Beider 2008, 416]. Wprawdzie ap. ros. igol'nik oznacza 'poduszkę lub pudełeczko do przechowywania igieł do szycia' (a także 'zbior.: opadłe igliwie') BTS 373, to leksem ten być może oznaczał też człowieka, zajmującego się wyrobem igieł do szycia. Taka profesja jest poświadczona w dokumentach doby średniopolskiej, por. n.os. Iglarz < iglarz [Rudnicka-Fira 2004, 155]. Por. też sufiks -nik w jęz. ros. wskazujący nazwy zawodów i wykonawców czynności, np. двор - дворник, лес-лесник, охота - охотник, работа - работник [Gużwa 1978, 201]; por. też Biryła 1966, 217.

10 Por. też n.os. Ковшевник BirBA $221<$ może od ros., stbrus. kowsz 'czerpak' - być może osoba produkująca naczynia tego typu.

11 Por. nazw. Sudnik w pracy Leonardy Dacewicz [2014, 397]: Sudnik< wschsł. sudnik 'niewielka ława w sieni, gdzie trzymano mleko i produkty spożywcze' (objaśnienie na podstawie: Dal). 
Szefler < śrwniem. scheffelcere, scheffeler 'bednarz' SENiem 221; Szkatulnik $<$ szkatulnik 'rzemieślnik wyrabiający szkatuły'12; Szklarz < szklarz 'rzemieślnik wprawiający szyby' SW VI 620; Sznajder < śrwniem. snīdœre, snīder 'ten, co coś odkrawa, odcina, krawiec' SENiem 228; Szwec < wschsł. gw. szwec 'szewc' AGWB I 100; Teszner < niem. n.os. Teschner, Taschner $<$ taschenmacher 'kaletnik' SENiem 267 (uszczuplenie części medialnej tematu); Tkacz < tkacz 'rzemieślnik, który zajmuje się tkaniem sukna, który robi tkaniny' SW VII 61; Zakrojszczyk< brus. zakrojszczyk, ros. zakrojszczik 'krojczy, zajmujący się cięciem tkaniny, skóry itp.' TSBM II 330, BTS 328; Zefejner $<$ może niem. n.os. Ziechner, Ziechener $<$ śrwniem. ziechener 'ten, co wyrabia poszewki na poduszki' SENiem 297; -ak: Cieślak - por. cieśla13; Krawczak - por. krawiec, wschsł. gw., ukr. kraweć 'rzemieślnik robiący ubrania' SW II 534, SGBP 108, SUM II 297; Zduniak - por. zdun 'rzemieślnik robiący garnki z gliny albo stawiający piece' SW VIII 424; -ek: Bednarekpor. bednarz; Pilarek - por. gw. pilarz 'ten, co drzewo piłuje, piłarz, tracz' SW IV 189; Zdunek - por. zdun ${ }^{14}$; -ik: Kowalik - por. kowal, wschsł. gw., ukr. kowa'l 'rzemieślnik wyrabiający grubsze rzeczy z żelaza' SW II 507, AGWB I 100, SUM II 260; Sznajdenik - por. śrwniem. snīdcere, snīder 'krawiec'; -ki: Szmydki - por. śrwniem. smit, śrdniem. smid 'kowal' SENiem 227; -ych: Szwajdych - por. szwajda 'szwaczka' RymNP II 562; -uk/-czuk: Bondaruk - por. wschsł. gw. bondar; Cieśluk - por. cieśla; Gonczaruk - por. brus. hanczar 'rzemieślnik, wyrabiający z gliny naczynia i inne przedmioty' TSBM II 26; Gontarczuk - por. gontarz 'człowiek robiacy gonty albo pokrywający nimi dachy, gonciarz' SW I 871; Kowalczuk, Kowaluk-por. kowal, wschsł. gw., ukr. kowál; Krawczuk-por. krawiec, wschsł. gw., ukr. kraweć; Kusznerczuk, Kuszneruk-por. kusznierz, brus. kusznier 'rzemieślnik szyjący futra i inne wyroby futrzane ze skór zwierzęcych' SW II 650-651, TSBM II 765; Puszkaruk - por. puszkarz, ros. puszkar' 'ten, co wyrabia broń palną, rusznikarz'15 SW V 442, BTS 1050; Stelmaszuk-por. stelmach 'rzemieślnik wyrabiający drewniane korpusy i części powozów i bryczek, kołodziej' SW VI 668; Szewczeniuk - por. szewczyna 'biedny, lichy szewc' SW VI 615; Szewczuk - por. szewc 'rzemieślnik robiący obuwie' SW VI 615;

\footnotetext{
12 Apelatyw nieodnotowany w słownikach języka polskiego. Antroponim Szkatulnik występuje w artykule Elżbiety Rudnickiej-Firy [2003, 209].

13 Pełne eksplikacje podawane są przy pierwszym cytowaniu znaczenia nazwy motywującej.

14 Por. też ap. zdunek 'kamień garnkowy, odmiana talku, z której wyrabiają naczynia kuchenne; zool. Nemesia - pająk czteropłucny' SW VIII 424.

15 Por. w artykule Leonardy Dacewicz [1993, 94-95] wschsł. puszkar, pol. puszkarz 'człowiek zajmujący się wyrobem armat'.
} 
Szklaruk - por. szklarz; Sznajderuk - por. śrwniem. snīdcere, snīder 'krawiec'; Teśluk - por. ukr. teśla 'cieśla' SUM IV 259; Tkaczuk - por. tkacz; Tokarczuk - por. tokarz, brus. tokar 'rzemieślnik zajmujący się toczeniem, formowaniem na tokarce' SW VII 76, TSBM V/1 494; Zduniuk-por. zdun; -yk/-czyk ${ }^{16}$ : Blecharczyk - por. blecharz 'wybielacz płótna, pilśniarz, wałkarz' SW I 164; Fularczyk - por. fularczyk < śrdniem. vuller 'folusznik' (Kreja 1998, 86)17, Lex I 174; Tkaczyk - por. tkacz; -ow: Boczarow - por. ros. boczar 'bednarz, wyrabiający beczki i inne naczynia drewniane' Ganż 72; Czebotariow - por. ros. czebotar' 'szewc' Ganż 534; -ewicz: Kowalewicz por. kowal, wschsł. gw., ukr. kowa'l; Krawcewicz-por. krawiec, wschsł. gw., ukr. kraweć; Tokarzewicz-por. tokarz; Zduniewicz-por. zdun; -owicz: Majstrowicz - por. majster 'najwyższy stopień przyznawany przez cech rzemieślników; rzemieślnik, który może samodzielnie prowadzić warsztat, rzemieślnik kierujący robotą; starszy pracownik' SW II 851, brus. majstar, ukr. majster 'specjalista $\mathrm{w}$ danej dziedzinie rzemiosła, produkcji' TSBM III 86, SUM II 398, wschsł. gw. majster 'majster, cieśla' SGBP 114, AGWB I 101; -enko: Tkaczenko - por. tkacz; mutylacja: Gornow - por. ros. gornowoj 'robotnik pracujący przy ognisku kowalskim' Uszak I 602.

Cytowany materiał pokazuje, że we współczesnych nazwiskach Podlasian spetryfikowane zostały różne branże rzemieślnicze: odzieżowo-obuwnicze (por. nazw. Krawcewicz, Krawczak, Krawczuk, Krawiec, Kusznerczuk, Kuszneruk, Płóciennik, Ptuciennik, Rezler, Sznajder, Sznajderuk, Szwajdych, Szwec, Teszner, Tkacz, Tkaczenko, Tkaczuk, Tkaczyk, Zakrojszczyk, Zefejner), drzewne (Bednarek, Bednarz, Boczarow, Bondar, Bondaruk, Cieśla, Cieślak, Cieśluk, Dudnik, Koleśnik, Kołodziej, Pilarek, Stelmach, Stelmaszuk, Sudnik, Szefler, Szkatulnik, Teśluk), metalowe (Gornow, Kowalczuk, Kowalewicz, Kowalik, Kowaluk, Pilarek, Puszkaruk, Szmydki), budowlane (Dykiert), garncarskie (Gonczaruk), szklarskie (Szklaruk, Szklarz), a także usługi łączące kilka fachów (Gontarczuk, Majstrowicz, Zdunek, Zduniak, Zduniewicz, Zduniuk).

Odrębnie należy potraktować określenia czeladników rzemieślniczych transponowane do kategorii nazwisk bez zmian formalnych: Bednarczyk $<$ bednarczyk 'terminator bednarski' SW I 110; Kowalczyk < kowalczyk 'czeladnik albo chłopiec kowalski' SW II 507; Krawczyk < krawczyk 'czeladnik albo chłopiec, uczeń, terminator krawiecki' SW II 534; Tokarczyk < tokar-

16 Słowniki nie poświadczają nazw terminatorów, ale istnienie takich określeń nie jest wykluczone (por. niżej).

17 Zdaniem Bogusława Krei [1998, 86], pierwotny fularczyk to byłby może nie 'pomocnik fularza', ale właściwa nazwa zawodowa, a więc 'folusznik'. Por. nazw. Fularczyk, Fularz, Fular, Folarz< nazw. niem. Füller < ap. vuller [tamże]. 
czyk 'terminator tokarski' SW VII 76; Zduńczyk < zduńczyk 'chłopiec, czeladnik zduński' SW VIII 424; Pachołek < pachołek 'czeladnik, terminator, uczeń rzemieślniczy' SW IV 3-4.

Uwage zwracaja przede wszystkim nazwiska z formantem -czyk, komponującym nazwy terminatorów, poświadczone w słownikach opisowych [por. Rudnicka-Fira 2004, 164-165]. Proces słowotwórczy towarzyszący powstaniu takich antroponimów mógł odbywać się także na innych płaszczyznach. Przyrostek -czyk tworzył w nazewnictwie osobowym formy hipokorystyczne, a od XVI w. także patronimiczne [Bubak 1986, 89; por. Kuć 2004, 107]. Ze względu na wielofunkcyjność tego sufiksu, etymonami nazwisk mogły być nazwy samodzielnych rzemieślników, a same antroponimy miałyby charakter struktur patronimicznych.

Warto zaznaczyć, że część nazw na -czyk, oprócz znaczenia 'terminator, czeladnik' wskazuje, że mamy do czynienia z synem rzemieślnika. To drugie objaśnienie odnotowane jest tylko w niektórych przypadkach. Na przykład, w Stowniku warszawskim leksemy bednarczyk, piwowarczyk, tokarczyk posiadają znaczenie 'syn [bednarza, tokarza, piwowara]', podczas gdy przy innych apelatywach (kowalczyk, kucharczyk, mlynarczyk, zduńczyk itd.) zawartość semantyczna zamyka się w znaczeniu 'uczeń [kowala, młynarza itd.], teminator'.

2. Kolejną grupę stanowią nazwy osób zajmujących się rolnictwem, pracami leśnymi i obróbką drewna, hodowlą zwierząt, łowiectwem i rybołówstwem. Określenia te znalazły odzwierciedlenie w następujących nazwiskach: Bortnik < wschsł. gw. bortnik 'bartnik' SGBP 24; Brajer < gw. brajer 'węglarz wypalający węgiel z drzewa w lesie' SGPRei II 450; Czaban $<$ czaban $^{18}$ 'pastuch wołów albo owiec' SW I 367; Fiszer < niem. fischer 'rybak' DN 185, RymNP I 195; Hajda < gw. hajda 'pastuch w górach' SW II 4; Hajduk < gw. hajduk 'gajowy' SW II 5; Kapustnik < kapustnik 'ogrodnik, zajmujący się sadzeniem kapusty' SW II 253; Koniuch < koniuch 'pasterz koni' SW II 442; Leśnik < leśnik 'człowiek znający się na leśnictwie' SW II 722; Ogrodnik < ogrodnik 'człowiek pracujący nad utrzymaniem ogrodu' SW III 719; Ostrychacz < gw. ostrycharz, ostrucharz 'ten, co trzebi zwierzęta domowe'19 RymNP II 189; Pasiecznik < pasiecznik 'pszczelarz'

18 O leksemie czaban zob. Rusek 1996, 39-40.

19 W SW ap. gw. ostrucharz (inaczej rostrucharz < niem. rosstäuscher) ma nieco inne znaczenie: 'ten, co handluje końmi, hodowca i sprzedawca koni'; 'ten, co handluje ludźmi'; 'pot. pośrednik w kupnie, stręczyciel' SW III 887, SW V 566-567. Może nazwisko to ma też powiązanie $\mathrm{z}$ ap. postrzygacz 'robotnik zatrudniony przy strzyżeniu owiec', ewentualnie w zn. 'ten, co strzyże ludziom włosy' SJPDor VI 1148 lub 'rzemieślnik od sukna' CieślO 101, por. Dacewicz 1993, 94; por. też wschsł. gw. ostryhati 'strzyc' (ostryhczy 'ostrzyc' SGBP 151). 
SW IV 74; Ptasznik < ptasznik 'hodowca drobiu; myśliwy ptaszy' SW V 423; Rybaczek < rybaczek - od rybak 'ten, co zajmuje się łowieniem ryb' SW V 781-782; Rybak < rybak, brus. rybák SW V 782, TSBM IV 732; Sadowy $<$ sadowy 'sadownik' SW V 4; Smolak < smolak 'ten, co wypala z drzewa smołę, smolarz' SW VI 243; -ak: Pastuszak - por. pastuch, brus. pastúch 'ten, co pasa zwierzęta domowe, co ich dogląda na pastwisku' SW IV 80, TSBM IV 92; -ek: Pilarek - por. gw. pilarz 'ten, co drzewo piłuje, tracz' SW IV 189; -uk/-czuk: Bortniczuk-por. wschsł. gw. bortnik; Rybaczukpor. rybak, brus. ryba'k; Smolarczuk - por. smolarz 'ten, co wypala z drzewa smołę' SW VI 243; Sterniczuk - por. gw. sternik 'żniwiarz przodownik' SW VI 418; Traczuk - por. tracz 'ten, co trze kloce na tarcicę piłą ręczną, pilarz' SW VII 90; -yk: Sadowniczyk - por. sadownik, sadowniczy 'ogrodnik sadowy' SW VI 3; Traczyk - por. tracz; -ski (-ska): Mastalerski-por. masztalerz, mastalerz 'człowiek zajmujący się końmi, gumienny' RymNP II 75; Myśliwska - por. myśliwy 'lubiący polować' SW II 1088; mutylacja: Flantz - por. niem. n.os. Pflanzer < śrwniem. phlanzcre 'plantator' SENiem 196.

3. Etymonami kolejnej grupy nazwisk Podlasian są nazwy osób związanych z przygotowywaniem pokarmów: Brajer < niem. brauer 'piwowar' RymNP I 51; Firlej < niem. vierlei < fürleger, vorleger 'krajczy' SW I 746, CieślO 37; Kichner < może niem. küchler 'ten, kto wypieka ciastka' RymNP I 393; Kuchta < kuchta 'pogardliwie o kucharzu albo kucharce' SW II 618; Kwaśnik < kwaśnik 'ten, który produkuje kwas' SHNOB I $200^{20} ;$ Litman $<$ n.os. Leit(h)man 'karczmarz, który szynkuje wino owocowe' SENiem 15721; Melcer < śrwniem. melzer 'słodownik' SENiem 173; Mielnik < gw. mielnik 'młynarz' SW II 956; Miitzner (!) < niem. Metzner, Matzner < metzger 'rzeźnik' RymNP II 81; Miller < śrdniem. moller, śrwniem. müller 'młynarz' SENiem 17322; Palacz < palacz 'destylator' SW IV 14; Piwowarczyk < piwowarczyk 'piwowar na małą skalę' SW IV 214; -ak: Olejniczak - por. olejnik 'ten, co wybija olej, olejarz' SW III 764; -ek: Mielczarek, Milczarek - por. mielcarz'dawniej: ten, który wyrabia słód, słodownik, piwowar' SW II 956, SJPDor IV 642, SStpl IV 226, RymNP II 92, CieślO 80; -uk: Kucharczuk, Kucharuk - por. kucharz, brus. kuchar 'ten, co gotuje' SW II 617, TSBM II 764; Mtynarczuk - por. mlynarz, brus. mtynar 'rzemieślnik, zajmujący się mieleniem zboża we młynie' SW II 1013, TSBM III 166; -ow: Winnikow - por. gw. winnik 'gorzelnik' SW VII 616.

20 W monografii Zofii Kalety [1998, 193] podstawą motywacyjną n.os. Kwaśnik jest ap. kwaśny.

21 Także w zn. 'ktoś, kto mieszka na zboczu góry' SENiem 157.

22 Por. też n.m. Melle k. Osnabrück + sufiks -er, za pomocą którego derywowano określenie, będące nazwą mieszkańca SENiem 173. 
Analizowany materiał poświadcza też kilka nazw terminatorów w funkcji współczesnych nazwisk: Kucharczyk < kucharczyk 'pomocnik kucharza' SW II 617; Młynarczyk < młynarczyk 'czeladnik, chłopiec młynarski' SW II 1013; Piwowarczyk < piwowarczyk 'czeladnik albo uczeń piwowarski; syn piwowara' SW IV 214.

4. Określenia osób trudniących się handlem także zostały spetryfikowane w nazwiskach używanych współcześnie przez mieszkańców omawianych miast: Budnik < gw. budnik 'kupiec, handlarz miejski, kramarz' SW I 226, CieślO 24; Kapustnik < kapustnik 'ogrodnik, zajmujący się sprzedawaniem kapusty' SW II 253; Korol < ros. korol' 'kapitalista będący liderem w jakiejśs dziedzinie przemysłu lub handlu' Uszak I 1472; Kwaśnik < kwaśnik 'ten, co sprzedaje kwas' TichA 73; Pacholek $<$ gw. pacholek 'subiekt kupiecki' SW IV 3-4; Płóciennik, Płuciennik < płóciennik 'handlarz sprzedający płótno' SW IV 266; Ptasznik < ptasznik 'handlarz ptaków' SW V 423; Rybaczek < rybaczek - od rybak 'handlarz ryb' SW V 781-782; Rybak < rybak; Sitarz < sitarz 'handlarz sitami' SW VI 120; Sitnik < ros. sitnik 'rzemieślnik handlujący sitami' Ganż 434; Szklarz < szklarz 'ten, co handluje szkłem' SW VI 620; -ko: Korolko - por. ros. korol'; -uk: Korolczuk, Koroluk - por. ros. korol'; Rybaczuk - por. rybak; Szklaruk - por. szklarz; -yk: Sadowniczyk - por. gw. sadownik 'przedsiębiorca zakupujący sady, tj. owoc na drzewach' SW VI 3; -ow: Salnikow - por. brus. salnik 'pot. handlarz tłuszczem' TSBM V/1 30; Winnikow - por. stbrus. winnik 'handlarz, sprzedawca wina' TichA 75 .

W nazewnictwie historycznym określenie indywidualne wskazujące na zawód nosiciela lub pełnioną przez niego funkcję stanowiło ważną cechę odróżniającą człowieka od innych mieszkańców. Dokładna identyfikacja była istotna także w przypadku niższych warstw społecznych. Wśród kupców, podobnie jak wśród rzemieślników, dana nazwa (a z czasem nazwisko) przechodząca z pokolenia na pokolenie stawała się czymś w rodzaju znaku firmowego [Dacewicz 1993, 96].

5. Kilka nazwisk nawiązuje do określeń osób, których zadaniem była ochrona obiektów: Budnik< budnik 'stróż przy sadzie, lesie, kolei' SW I 226; Hajduk < gw. hajduk 'gajowy', 'dozorca' SW II 5; Leśnik < leśnik 'stróż leśny, gajowy, borowy' SW II 722; Pachotek < pachotek 'stróż karczemny u Żydów arendarzy' SW IV 3-4; Smolak < smolak 'strażnik pograniczny w lesie' SW VI 243; Pasiecznik < pasiecznik 'dozorca pasieki' SW IV 74; -uk: Cieciuk - por. cieć 'stróż' SW I 322.

6. Pochodzenia części nazwisk można doszukać się w nazwach osób pełniących funkcje dworskie: Dworak $<$ dworak 'człowiek pracujący na folwarku, sługa dworski' SJPDor II 449, SXVI VI 253, SGP I 403; Hajduk< brus. 
hajduk 'sługa lub lokaj w czasach prawa pańszczyźnianego' TSBM II 14; Konarska < konarski 'urzędnik sprawujący zarząd nad stajnią czy stadninami królewskimi lub książęcymi' SStpl III 325; Pachotek < pachołek 'sługa, służący, parobek, czeladnik' SW IV 3-4; -czyk: Dworańczyk-por. gw. dworan 'człowiek należący do czeladzi dworskiej, pachołek, służący' SW I 595.

W większości przypadków nazwy motywujące oznaczają posady o niskim statusie, ponieważ wykonawcy określani w ten sposób pełnili funkcje służebne. Urzędnikiem wyższej rangi (względem pozostałych w tej grupie) był konarski (> nazw. Konarska).

7. Od samego początku człowiekowi towarzyszyła muzyka. Instrumenty, za pomocą których wydobywano dźwięki od najbardziej prymitywnych do zaawansowanych technologicznie były wykorzystywane nie tylko jako urozmaicenie egzystencji, ale również w pracy, jako narzędzie komunikacji, w obrzędach magicznych i religijnych. Swoje nazwy otrzymały osoby w różny sposób związane z poszczególnymi instrumentami - zawodowo, bardziej amatorsko lub zupełnie okazjonalnie. W podstawach nazwisk występujących współcześnie na Podlasiu odnajdujemy pewną liczbę określeń związanych z tym polem znaczeniowym, por.: Basista < basista 'ten, co gra na basetli, basetlista' SW I 103; Dudnik < ros. dudnik 'muzykant, grający na piszczalce' Ganż 175; Fidler < śrwniem. videlare, vidler, śrdniem. veddler, vedelēre 'skrzypek' SENiem 49; Kobzar < brus. kabzar 'ukraiński śpiewak ludowy, śpiewający pod akompaniament kobzy' TSBM II 569; Smyk < smyk 'grajek jarmarczny' SW VI 249; Surmacz < surmacz, brus. surmácz 'ten, co gra na surmie' SW VI 516, TSBM V/1 390; -ewicz: Muzykiewicz-por. muzyk 'artysta, zajmujący się muzyką, kompozytor albo wirtuoz'; 'śpiewak; brus. muzyka 'pot. muzykant' TSBM III 179; -ko: Grajko - por. grajek 'muzykant, pieśniarz' (-ek>-ko) SW I 898.

8. Etymonami nazwisk mogły być okazjonalne określenia ludzi, nierzadko związane z przypadkowym wykonywaniem zajęcia lub chwilowym pełnieniem jakiejś funkcji [Raszewska-Klimas 2018, 91]: Drużba $<$ drużba 'mężczyźni asystujący przy ślubie' SW I 566; Krzyżak< gw. krzyżak 'człowiek, który niesie krzyż przed procesją' SW II 603, Marszatek < marszatek, brus. marszałak, wschsł. gw. marszałok 'starszy drużba na weselu, wodzirej weselny' SJPDor IV 473, SXVI XIII 175, TSBM III $113^{23}$.

Ze względu na semantykę trudno odnieść powyższe przykłady do nazw zawodów sensu stricto, bliższe są one przezwiskom powstałym w warunkach

23 W AGWB (s. 104) ap. marszałok jest objaśniany w inny sposób: 'swat (starszy człowiek, który idzie w swaty z kawalerem)'. 
sprawowania przez nosiciela okazjonalnych funkcji o charakterze jednorazowym lub powtarzalnym.

Na ustalenie się określeń tego typu w charakterze nazw własnych mogły mieć wpływ różne motywy ekstralingwistyczne. Na przykład, miano Krzy$\dot{z} a k$ mogło zostać nadane człowiekowi noszącemu krzyż w procesji cyklicznie przez wiele lat, a więc osobie cieszącej się szacunkiem w określonej mikrowspólnocie i kojarzonej z wykonywaniem tej funkcji od dawna. W takim przypadku można mówić o użyciu wyrazu motywującego w jego podstawowym, neutralnym znaczeniu. Mogła jednak wystąpić zupełnie odmienna sytuacja: wskutek zaistnienia pewnych okoliczności, zadanie zostało powierzone osobie przypadkowej, której wybór był zaskoczeniem dla uczestników sytuacji komunikacyjnej. To jednorazowe zdarzenie mogło utkwić w pamięci danej społeczności na tyle, że wykonawcy czynności zostało nadane przezwisko Krzyżak, które in statu nascendi posiadało (ujemne, jak można przypuszczać) nacechowanie emocjonalne.

9. Wiara w moce nadprzyrodzone, rządzące światem i losem człowieka jest częścią ludzkiej natury. Pojęcia magia i religia również istnieją w każdym języku, a związana z nimi leksyka wystąpiła w podstawach motywacyjnych następujących nazwisk: Kardynat < kardynat 'duchowny, piastujący najwyższą po papieżu godność kościelną'; 'dawniej: każdy urzędnik duchowny przy jakimkolwiek kościele głównym' SW II 266-267; Kirchner < niem. kirchner 'kościelny'; Mnich < mnich 'duchowny, żyjący pod regułą, zakonnik' SW II 1015; Monach < wschsł. gw., ukr., ros. monach 'mnich, zakonnik' SGBP 115, SUM II 444, Uszak II 254; $\dot{Z} a k<\dot{z} a k$ 'kościelny, organista, klecha, kleryk' SW VIII 684, 686; -ik: Popik - por. pop 'duchowny prawosławny, ksiądz unicki'; 'kapłan niechrześcijański, ofiarnik'; 'ksiądz katolicki' SHNOB II 43, SW IV 638; -ko: Popko - por. pop; -yło: Buryło - por. lit. būras 'znachor, czarodziej' KonNBB 131; -owicz: Monachowicz - por. monach; -ewicz: Magosiewicz - por. magus 'kapłan u starożytnych Persów, zajmujący się także astrologią i magią; czarnoksiężnik, wróżbita' SXVI XIII 18; -ow: Popow - por. pop; mutylacja i $\varnothing>$ a: Kolata - por. może kolator (z łac. collator 'ofiarodawca') 'dawn. patron, fundator kościoła, który miał prawo przedstawiania biskupowi kandydata na wakujące beneficjum przy kościele Kop 267.

Najwięcej określeń dotyczy stanowisk i godności obecnych w kościołach chrześcijańskich. Chrystianizacja Słowiańszczyzny przyniosła nie tylko nową kulturę i wartości, skutkowała też pojawieniem się w zasobie leksykalnym nowego słownictwa, do którego w pierwszej kolejności należy zaliczyć pojęcia związane z organizacją życia religijnego. Tylko pojedyncze apelatywy nawiązują do funkcji charakterystycznych dla innych konfesji (por. magus, 
częściowo także pop (zob. wyżej)) lub związanych z obrzędami magicznymi (būras, magus).

10. Etymonami nazwisk kolejnej grupy są nazwy mające źródło w leksyce związanej z wojskowością i innymi służbami mundurowymi: Bobik < brus. bobik 'pogardliwie o mieszkańcach, zwerbowanych przez okupantów faszystowskich najeźdźców do służby w policji w czasie wielkiej wojny ojczyźnianej' TSBM I 391; Dobosz < dobosz 'żołnierz, który bębni' SW I 471; Dragun < dragun, ros. dragún, brus. drahún 'kawalerzysta, pełniący służbę pieszo i konno' SW I 549, TSBM II 194, Ganż 168; Hajduk< hajduk ‘żołnierz piechoty węgierskiej, która istniała w Polsce od początku do połowy XVII w., a później służyła w kompaniach piechoty hetmańskiej'; 'u Słowian na pograniczu Turcji: człowiek, prowadzący wojnę z Turkami na własny rachunek'; 'policjant na Wegrzech, pachołek policyjny' SW II 5; brus. haj$d u k$ 'powstaniec na Bałkanach i na Węgrzech, walczący z niewolą turecką i prawem feudalnym' TSBM II 14; Janczar < janczar 'żołnierz piechoty tureckiej' SW II 133-134; Krzyżak < krzyżak 'rycerz zakonu braci szpitalnych albo teutońskich; rycerz ormiański' SW II 602-603; Pacholek < pacholek 'giermek przeznaczony do noszenia kopii w dawnej jeździe polskiej i mający pod sobą konie na zmianę dla pana'; 'żołnierz szeregowy w jeździe i piechocie polskiej' SW IV 3-4; Porucznik < porucznik 'stopień oficerski, lejtnant; w dawnej Rzeczypospolitej: druga osoba po rotmistrzu w kawalerii, drugi stopień oficerski w armii Królestwa Polskiego' SW IV 722; -czyk: Atamańczyk - por. ataman 'hetman, naczelny dowódca Kozaków' SW I 67; -'ok: Hetmaniok - por. brus. hetman 'w XVI-XVII w. na Ukrainie - naczelnik wojska kozackiego; 'w XVI-XVIII w. - dowódca wojskowy w Wielkim Księstwie Litewskim i w Polsce' TSBM II 47; -uk: Drabiuk-por. stbrus., stpol. drab 'żołnierz, piechur'24 TichA 72; Puszkaruk - por. pol. puszkarz, ros. puszkar' 'artylerzysta, kanonier' SW V 442, BTS 1050; -un: Baszun por. basza 'dygnitarz wojskowy w dawnej sułtańskiej Turcji' SXVI II 26; -owicz: Majorowicz - por. major 'oficer wyższy od kapitana, ale niższy od podpułkownika' SW II 850; -ew: Kniaziew - por. kniaź 'dowódca wojskowy na Rusi okresu feudalnego' TSBM II 706.

Większość baz fundujących to określenia stanowisk lub stopni wojskowych (względnie innych formacji mundurowych). Uwage zwraca spory odsetek nazw o zróżnicowanej „geograficznie” semantyce. Przyczyn ich obecności w analizowanym zasobie należy upatrywać w wydarzeniach historycznych, przede wszystkim o charakterze zbrojnym, prowadzonych na obszarze

24 Por. też ap. $d r a b$ 'człowiek wysoki, niezgrabny; biedak' SHNOB I 78. 
Słowiańszczyzny. W tych przypadkach, jak można sądzić, nazwa własna rzeczywiście odpowiadała faktycznemu zajęciu pierwotnego nosiciela. Nie jest też wykluczone, że antroponimy miały zabarwienie przezwiskowe, być może o ironicznym ładunku emocjonalnym, a ich kreacji towarzyszyły stereotypy inicjowane pochodzeniem etnicznym osoby identyfikowanej, powiązane z uprzedzeniami i awersją na tle narodowościowym.

11. Stosunkowo licznie $\mathrm{w}$ funkcji podstaw słowotwórczych wystąpiły nazwy godności i urzędów państwowych: Car < car SW I 255; Korol < ros. korol' 'król' BTS 459; Król < król 'najwyższy zwierzchnik państwa, monarcha' SW II 566-567; Porucznik < stpol. porucznik 'pełnomocnik, posłannik, namiestnik, zastępca' SW IV 722; Rejent < rejent 'urzędnik sądowy spisujący umowy stron, akty darowizny, dzierżawy, kontrakty, testamenty itp.' SW V 503; Rzaca < rzonca, rząnca, rzańca, gw. rzonca, rzońca 'ten, co rządzi, zarządca, rektor, administrator, władca, naczelnik, kierownik, nadzorca' SW V 803 (por. n.os. Rzańca, Rzanca) [Rudnicka-Fira 2003, 210]; Se$d z i a k<$ stpol. sędziak 'najwyższy urzędnik u Izraelitów przed ustanowieniem królestwa; niby naczelnik powiatu w Turcji, sandżak' SW VI 29, 78²5; Soltys $<$ sołtys 'najniższy urzędnik administracyjny wiejski, przełożony nad jedną z kilku wsi tworzących gminę'; 'wójt' SW VI 266; Wójcik< wójcik-zdr. od wójt 'prezes rady miejskiej, najwyższy z urzędników miejskich'; 'zwierzchnik gminy wybierany z grona właścicieli gruntów'; 'sołtys, przełożony nad gromadą wiejską, sędzia wiejski'; 'dawniej: jeden z włościan poddanych, obowiązany do wypędzania na pańszczyznę, pilnowania robotników i zdawania o nich sprawy przed ekonomem' SW VII 703-704; -ak: Woźniak - por. woźny 'niższy oficjalista sądowy, sługa sądowy' SW VII 702; -ek: Tywonekpor. brus. ciwun 'urzędnik ziemski w województwach Wileńskim i Trockim oraz na Żmudzi'; 'włodarz, podstarości, rządca, gumienny, dozorca robót' SW I 342; -ko: Korolko - por. ros. korol' 'król' BTS 459; -'ok: Hetmaniok - por. brus. hetman 'w XVII-XVIII w. - najwyższy władca na Ukrainie' TSBM II 47; -uk/-czuk: Ciwoniuk - por. brus. ciwun; Korolczuk, Koroluk - por. ros. korol'; Lawniczuk - por. tawnik 'sędzia poboczny, sędzia z ludu, rodzaj asesora'; 'urząd w magistracie' SW II 802; Strapczuk - por. strapczy 'prokurator powiatowy w Rosji' SW VI 445; -un: Baszun - por. basza 'dygnitarz cywilny w dawnej sułtańskiej Turcji, pasza' SXVI II 26, SW I 104; -czyk: Atamańczyk - por. ataman 'na Ukrainie: pomocnik ekonoma, wójt po wsiach i miasteczkach' SW I 67; -owicz: Szachowicz-por. szach 'monarcha perski' SW VI 550; Wojtowicz-por. wójt; -ew: Kniaziew-por. kniaź

25 Por. też ap. sędzia $(+-a k)$. 
'dowódca wojskowy i gubernator na Rusi okresu feudalnego' TSBM II 706; -ski: Witerski - por. niem. witter < witehere 'radny' RymNP II 688.

Jak można zauważyć, kilka określeń wystąpiło również w grupie poprzedniej. Zdarzają się bowiem sytuacje, w których piastowanie danego urzędu wiązało się z wykonywaniem obowiązków zarówno administracyjno-urzędowych, jak też militarnych (por. ataman, basza, hetman, kniaź, porucznik). Podobnie jak w przypadku nazwisk od określeń wojskowych, także antroponimy od nazw funkcji i urzędów państwowych mogły w wielu przypadkach mieć charakter ironiczny i przezwiskowy.

12. Określenia wskazujące na stan społeczny znajdują się na peryferiach zasobu definiowanego jako nazwy zawodów, godności i urzędów. Niemniej, uwzględnienie tych leksemów wydaje się zasadne z uwagi na odmienne, względem epoki współczesnej, uwarunkowania społeczno-ekonomiczne w czasach historycznych. Inna była wówczas struktura ludnościowa, a w społeczeństwie stanowym przynależność do tej czy innej warstwy automatycznie pociągała za sobą pełnienie określonych funkcji, wynikającej z pozycji prawnej i ekonomicznej. Na przykład, bycie właścicielem majątku lub dziedzicem oznaczało bycie gospodarzem. Osoba będąca dworzaninem zajmowała wysokie stanowiska w otoczeniu panującego monarchy, korzystając przy okazji z licznych przywilejów przyznawanych przez władcę. W cytowanym zbiorze określenia związane z pozycją socjalną nie są licznie reprezentowane, ale stanowią cenny nośnik pamięci o funkcjonowaniu społeczeństw w przeszłości, por.: Budnik < budnik 'włościanin z Królestwa osiadły na Polesiu, na prawie czynszowym' SW I 226; Dworaczek < dworaczek - zdr. od dworak 'dworzanin króla albo magnata' SJPDor II 449, SXVI VI 253, SW I 593-594; Dworak < dworak; Dziedzic < dziedzic 'dziedziczny pan, właściciel'; 'właściciel majątku ziemskiego' SW I 638; Ofman < niem. hofmann 'dworzanin' RymNP I 309; Potentas < może potentat (z łac. potentatus) 'możnowładca, magnat' SW IV 803; -czyk: Dworańczyk - por. gw. dworan 'człowiek należący do dworu monarchy albo magnata; dworzanin' SW I 595.

13. Ostatnią grupę tworzą nazwiska, zawierające w bazach fundujących określenia funkcji i zawodów, które ze względu na semantykę trudno zaszeregować do któregokolwiek z powyższych zbiorów: Godun < wschsł. gw. hodun 'wychowanek' AGWB I 98; ukr. hodun 'karmiciel' SUM I 299; Chworoś $<$ foryś 'pomocnik stangreta, woźnica' SHNOB I 59; Fleger < niem. pfleger 'pielęgniarz, opiekun'; Furmanek < furmanek 'biedny, potulny furman' SW I 785 (może też zdr. od furman 'woźnica, trudniący się przewożeniem towarów'); Grabarz < grabarz 'człowiek zajmujący się kopaniem grobów' SW I 892; Konefat < gw. konefat 'lekarz zwierząt, weterynarz, konowal'; człowiek bez nauki, partacz leczący bydło i konie; przen. lekarz zły, nieludz- 
ki'; gw. konefał urzędnik, układający w spokojnym miejscu gości, zamroczonych trunkiem i chcących się przespać' SW II 445-446; Palacz< palacz 'ten, co pali w piecu i podtrzymuje ogień' SW IV 14; Porucznik < stpol. porucznik 'osoba, której coś poruczono, pełnomocnik, posłannik, zastępca' SW IV 722; Stawarz < stawarz 'kopacz stawów' SW VI 407; Żak < żak 'uczeń szkolny, uczniak, bakalarz' SW VIII 686; stpol. żak 'uczony, literat' SW VIII 686; -ak: Gumieniak - por. gumiennik, gumienny 'dozorca gumna albo robót gumiennych' SW I 940-941; -uk: Furmaniuk - por. furman 'woźnica, trudniący się przewożeniem towarów' SW I 785; Stangryciuk por. stangret, zdr. stangrecik 'woźnica, powożący' SW VI 390; Sterniczuk - por. sternik 'ten, co kieruje sterem, kierownik statku'; 'przen. kierownik, dyrektor, rządca, przewoźnik' SW VI 418; -ow: Narasow - por. lit. nãras 'nurek' LLKŻ 265, LPŻ II 295; -ew: Tołkaczew - por. ros. tołkacz 'robotnik zajmujący się ręcznym przesuwaniem jakichś rzeczy' Uszak IV 727.

W zacytowanych nazwiskach zostały spetryfikowane nazwy profesji bądź pełnionych funkcji o charakterze stałym lub okazjonalnym, często związanych z świadczeniem usług w zależności od zapotrzebowania na nie (por. np. grabarz, stawarz). W niektórych przypadkach trudno wnioskować nawet o przybliżonym okresie parania się danym zajęciem, wyrażonym apelatywem (np. hodun, palacz). Część określeń posiada bardzo szerokie znaczenie obejmujące wiele aspektów, co nastręcza trudności przy ich klasyfikacji semantycznej, por. np.: porucznik, palacz, sternik (por. oba znaczenia), tołkacz.

III. Największac produktywnością w tworzeniu nazwisk analizowanych w niniejszym opracowaniu odznaczają się nazwy rzemieślników różnych specjalności ${ }^{26}$. Niektóre nazwiska motywowane od określeń tych profesji można rozpatrywać paralelnie jako antroponimy pochodzące od nazw handlarzy. Takie kilkuaspektowe znaczenie mają bowiem apelatywy motywujące, np. Płóciennik (por. płóciennik 'tkacz wyrabiający płótno; handlarz sprzedający płótno') [zob. Czopek-Kopciuch 2004, 29], Szklarz, Szklaruk (por. szklarz 'rzemieślnik wprawiający szyby; ten, co handluje szkłem')27. Mniej licznie występują określenia, które nazywają osoby zajmujące się rolnictwem, leśnictwem, rybołówstwem i produkcją wyrobów spożywczych, przy czym niektórzy z tych pracowników również są obecni w branży handlowej. Odmienny nieco charakter mają nazwy osób pełniących funkcje społeczne

\footnotetext{
26 Jest to tendencja powszechna [por. Lech 2003, 222].

$27 \mathrm{Na}$ podwójne znaczenie apelatywów, z których jedno jest związane ze sferą handlu zwraca również uwagę Hanna Buczko [2010, 224].
} 
i urzędy. Tu najliczniej reprezentowane są nazwiska od nazw osób piastujących stanowiska państwowe. Jak zaznacza Hanna Buczko [2010, 224], nazwiska typu Car, Szach (por. nazw. Szachowicz) powstały najpewniej od przezwisk indywidualnych, a nie od realnych określeń danej osoby. Z pełnieniem funkcji państwowej nie należy wiązać też nazwisk typu Korol, Korolczuk, Koroluk. Stosunkowo duża popularność nazwisk z leksemem korol może wskazywać na osobę, zamieszkującą lub obrabiającą „królewszczyznę", tj. ziemię należącą do dóbr królewskich. Inne nazwiska pochodzą od nazw osób, które mogły pełnić funkcje religijne, wojskowe, dworskie. Wyodrębniono nieliczną grupę nazwisk pochodzących od nazw osób związanych z muzyką lub pełniących funkcje okazjonalne.

Elżbieta Rudnicka-Fira [2003, 208] zauważa, że większość nazwisk odzawodowych pod względem strukturalnym jest równa apelatywom o różnych przyrostkach, udokumentowanym w słownikach języka polskiego. Stanowisko to potwierdzają badania Lilii Citko [2001, 90-92] z terenu północnego Podlasia w XVI w. oraz Leonardy Dacewicz [1993, 97] w zakresie antroponimów dawnego województwa podlaskiego w XVI-XVII w. Materiał współczesny z Bielska Podlaskiego, Hajnówki i Siemiatycz również wskazuje na dominację nazwisk będących przeniesieniami nazw pospolitych. Należy jednak zaznaczyć, że brak apelatywu (z danym formantem) poświadczonego w leksykonach nie upoważnia do automatycznego potraktowania nazwy z tym sufiksem jako derywowanej na poziomie antroponimicznym. Istnieje bowiem możliwość, że tego typu określenia powstały w języku mówionym i początkowo nie miały jeszcze funkcji nazwy [por. Sieradzki 2010, 265-266; Dacewicz 2014, 157].

Z językowego punktu widzenia dominują nazwy polskie. Mniejszą frekwencją odznaczają się apelatywy pochodzenia wschodniosłowiańskiego, bałtyckiego i niemieckiego. Cytowany materiał zaświadcza obecność we współczesnej antroponimii Podlasia nazwisk pochodzących od znaczeniowo tożsamych, ale zróżnicowanych językowo nazw zawodów i godności, por. Król - Korol; Cieśla - Teśluk - Dojlida; Szewc - Szwec [por. też Czopek-Kopciuch 2004, 36] - Czebotariow - Rezler; Rybak - Fiszer; Krawiec - Sznajder, Sznajderuk; Kowal - Szmydki; Mtynarz - Mlynarczuk - Miller; Mnich - Monach; Bednarz - Bondar, Bondaruk - Boczarow - Sudnik - Szefler; Sitarz - Sitnik. Współwystępowanie różnych językowo określeń tych samych zawodów jest cechą typową dla obszarów mieszanych pod względem etnicznym [Dacewicz 1993, 96]. O zawiłościach wynikających ze zróżnicowania językowego podstaw motywujących można mówić nie tylko w kontekście powyższych paraleli. Złożoność przejawia się też na innych płaszczyznach. Na przykład, źródeł niektórych leksemów trzeba szukać w innych językach, 
niż ten, w którym wyrazy funkcjonują już jako elementy zadomowione i są brane pod uwage przy ustalaniu baz słowotwórczych antroponimów. Także nazwy zawodów i godności używane na Słowiańszczyźnie etymologicznie związane są z innymi językami, często nierodzimymi, np. ap. basza, czaban pochodzą z języka tureckiego, hajduk - z węgierskiego, pop - z greckiego, a także z innymi słowiańskimi, np. mas(z)talerz - z czeskiego, strapczy z rosyjskiego. Leksemy kolator, potentat są spolszczonymi formami rzeczowników łacińskich.

IV. Zasygnalizowane we wstępie kwestie - statusu nazw odzawodowych w systemie apelatywno-proprialnym i wielofunkcyjności formantów komponujących nazwiska to nie jedyne problemy interpretacyjne. Trudności moga też mieć związek z przedstawieniem zasobu wyrazów pospolitych przy analizie nazwisk utworzonych na ich bazie. Aleksandra Cieślikowa [1990, 11] do takich barier zalicza m.in. wielomotywacyjność towarzyszącą powstaniu konkretnego nazwiska. Innym czynnikiem są homonimia i polisemia apelatywów, uniemożliwiające rekonstrukcję znaczenia danego apelatywu w konkretnej sytuacji nazw(isk)otwórczej. Przyczyny takiego stanu rzeczy zawierają się w przezwiskowym charakterze nazw odapelatywnych i w znaczeniu aktualnym wyrazu stanowiącego podstawę kreacji antroponimu. Trzeba również uwzględnić, że w tworzeniu nazwy własnej mogą być brane pod uwagę różne zakresy semantyczne leksemu motywującego. Eliminacji mogą być poddane znaczenia peryferyjne, metaforyczne, ale redukcja może też obejmować znaczenia podstawowe i wówczas nazwa własna opiera się na znaczeniu drugorzędnym, nierzadko okazjonalnym [Rymut 1987, 317-318].

Materiał z Podlasia pokazuje, że wielomotywacyjność w ujęciu etymologicznym w stosunkowo niewielkim stopniu rzutuje na trudności w ustaleniu pochodzenia nazwisk (np. Dudnik < dudnik lub dudnić 'huczeć, bębnić'; Kowalik < kowal lub kowalik 'zool. Sitta - gat. ptaka'; Kwaśnik < kwaśnik lub kwaśny; Zdunek< zdun lub zdunek 'kamień garnkowy', zdunek 'zool. Nemesia - pająk czteropłucny i in.). Znacznie częściej mamy do czynienia z wieloznacznością wyrazów, będących domniemaną bazą słowotwórczą. W przedstawionym wyżej podziale nazwisk współczesnych poszczególne znaczenia etymonu mieszczą się w obrębie jednego pola semantycznego (np. ciwun, kardynat, pop, wójt), lub reprezentują różne zbiory (np. budnik, krzyżak, palacz, rybak, winnik, $\dot{z} a k$ ). Niektórym leksemom można przypisać cały szereg znaczeń, z których każde mogło hipotetycznie pełnić funkcję podstawy motywującej (por. np. hajduk, pachotek, wójt). Niezgodność zawartości semantycznej może cechować się różnym stopniem, czasami mogą to być nawet znaczenia przeciwstawne, jak w przypadku ap. dworak. 
Kwestia wielomotywacyjności łączy się niekiedy z zagadnieniem zróżnicowania językowego. Oprócz typowych przypadków homonimii językowej (typu bednarz - bondar), różne potraktowanie danego leksemu może wynikać $\mathrm{z}$ jego odmiennego znaczenia w języku ogólnonarodowym i w gwarach (por. np. budnik, konefat, sternik). Różne okresy w historii języka także znajdują odzwierciedlenie w badanym materiale, np. w polszczyźnie współczesnej ap. $\dot{z} a k$ 'uczeń szkolny, uczniak, bakalarz' i stpol. $\dot{z} a k$ 'uczony, literat'.

Inne dylematy uwidaczniają się na poziomie strukturalnym. Trudno bowiem ustalić $\mathrm{w}$ procesie derywacyjnym moment, w którym miała miejsce sufiksacja. Sytuację tę komplikuje fakt, że formy zdrobniałe części leksemów sa poświadczone jako apelatywa w słownikach opisowych (np. dworaczek, furmanek, rybaczek), a przecież inne formacje tego typu również mogły funkcjonować w języku mówionym jako nazwy pospolite.

Jak podkreśla Aleksandra Cieślikowa [1990, 14], „Najwnikliwsze analizy danych antroponimicznych nie są w stanie uchronić przed wielomotywacyjną interpretacją nazw osobowych". Badania potwierdzają owe trudności, nawarstwiające się zwłaszcza przy analizie nazwisk współczesnych w aspekcie statycznym. Wobec braku kontekstu sytuacyjnego ustalenie rzeczywistego (a nie potencjalnego) wyrazu motywującego jest szczególnie problematyczne.

V. Interesująco przedstawia się też porównanie materiału współczesnego ze zbiorem XVI-XVII-wiecznych nazw odzawodowych zanotowanych na terenie dawnego woj. podlaskiego [Dacewicz 1993, 93-99]. Jedynie około połowy określeń wykorzystywanych w tworzeniu formacji identyfikujących osoby $\mathrm{w}$ czasach historycznych pojawia się w badanym zasobie nazwisk używanych w XXI w. Do takich nazw należą m.in. bednarz, bondar, ciwun, kusnierz, kowal, krawiec, tawnik, wojt, mastalerz, pop, puszkar, smolarz, sołtys, winnik, zdun. Współczesna baza źródłowa nie poświadcza z kolei takich leksemów, jak barwierz, bronowłok, kamasznik, kołbnik, koziemiaka, marszałek, piwniczy, posol, siodlarz, szapowat, szkutnik, zielnik i in. Można zatem wnioskować, że część określeń przechodziła z pokolenia na pokolenie zachowując się do naszych czasów w podstawach nazwisk. Inne nazwy być może rzeczywiście funkcjonowały jako mniej lub bardziej zantroponimizowane określenia zawodów lub piastowanych urzędów, używane w celu dokładniejszej identyfikacji nosiciela, nie posiadały one jednak charakteru dziedzicznego.

Zwraca także uwagę obecność wyrazów pochodzenia niemieckiego w podstawach antroponimów współczesnych wobec niemal całkowitego ich braku w źródłach dawnych. W dokumentach historycznych [zob. Citko 
2001; Dacewicz 1993; Złotkowski 2002, Złotkowski 2015, Złotkowski 2016, Złotkowski 2017] germanizmy na Podlasiu występują (w zakresie badanych nazw) nadzwyczaj sporadycznie i dotyczą przede wszystkim leksemów zakorzenionych na gruncie słowiańskim (np. landwójt, stangret, stelmach).

VI. Nazwiska pochodne od określeń zawodów, godności, funkcji i urzędów stanowią ciekawy obiekt badawczy nie tylko z perspektywy czysto językoznawczej. Dostarczają informacji o kulturze i poziomie cywilizacyjnym społeczeństw, o zajęciach i zainteresowaniach ludzi je tworzących [Rudnicka-Fira 2003, 209; Rudnicka-Fira 2004, 156]. Nazwiska stanowią też cenne źródło poznania nazw samych zawodów, szczególnie nieznanych w czasach obecnych [Rusek 1996, 10]. Jak się wydaje, rozwój cywilizacyjny i procesy związane z postępem naukowo-technologicznym wpływają na poszerzanie się repertuaru zawodów uznawanych za anachroniczne. Nazwy niektórych profesji, powszechnie wykonywanych jeszcze 10-20 lat temu, na początku XXI wieku mogą być już zaliczone do przestarzałych. Wiedzę historyczną wzbogacają też nazwiska od określeń funkcji i stanowisk, których żywotność jest ograniczona ramami czasowymi, a czasami również terytorialnymi.

\section{Wykaz skrótów}

AGWB - Atlas gwar wschodniostowiańskich Białostocczyzny, 1980, pod red. S. Glinki, A. Obrębskiej-Jabłońskiej, J. Siatkowskiego, t. I, Wrocław-Warszawa-Kraków-Gdańsk.

BirBA - Бірыла М.В., 1966, Беларуская антрапанімія. Уласныя імёны, імёнь-мянушкі, імёны па бачьку, прозвішчьл, Мінск.

BTS - Кузнецов С.А., 2001, Большой толковый словарь русского языка, Санкт-Петербург.

CieślO - Cieślikowa A., 1990, Staropolskie odapelatywne nazwy osobowe. Proces onimizacji, Wrocław-Warszawa-Kraków.

Dal - Даль В.И., 1880-1882, Толковый словарь живого великорусского языка, т. I-IV, Санкт-Петербург-Москва.

DN - Gottschald M., 1971, Deutsche Namenkunde. Unsere Familiennamen nach ihrer Entstehung und Bedeutung, Berlin.

Ganż - Ганжина И.М., 2001, Словарь современных руссих фамилий, Москва.

Gr-Med - Грушко Е.А., Медведев Ю.М., 1998, Фамилии..., Москва. 
KonNBB - Kondratiuk M., 2000, Nazwiska pochodzenia battyckiego w regionie białostockim, „Acta Baltico-Slavica” 25, s. 123-150.

Kop - Kopaliński W., 1990, Stownik wyrazów obcych $i$ zwrotów obcojęzycznych, Warszawa.

LauSB - Лаучюте Ю.А., 1982, Словарь балтизмов в славянских языках, Ленинград.

Lex - Lexikon der Familiennamen polnisher kerkunft im Ruhrgebiet, 20062010, hrsg. von K. Rymut, J. Hoffmann, bearb. B. Czopek-Kopciuch, t. 1-2, Kraków.

LLKŻ - Kalèda A., Kaledienė B., Niedzviecka M., 1991, Lietuviu-lenku kalbu žodynas, Vilnius.

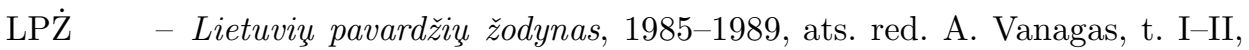
Vilnius.

RymNP - Rymut K., 1999-2001, Nazwiska Polaków: słownik historyczno-etymologiczny, t. 1-2, Kraków.

SENiem - Stownik etymologiczno-motywacyjny staropolskich nazw osobowych. Częśc 5. Nazwy osobowe pochodzenia niemieckiego, 1997, opr. Z. Klimek, Kraków.

SGBP - Wróblewski M., 2008, Stownik gwary bielsko-podlaszskiej, Bielsk Podlaski.

SGP - Stownik gwar polskich, 1900-1911, pod red. J. Karłowicza, t. I-VI, Kraków.

SGPRei - Stownik gwar polskich, 1981, t. 2, pod red. J. Reichana, Wrocław-Kraków.

SHNOB - Abramowicz Z., Citko L., Dacewicz L., 1997-1998, Stownik historycznych nazw osobowych Białostocczyzny (XV-XVII w.), t. I-II, Białystok.

SJPDor - Stownik jezzyka polskiego, 1958-1969, pod red. W. Doroszewskiego, t. 1-11, Warszawa.

SStpl - Stownik staropolski, 1953-, pod red. S. Urbańczyka, t. 1-, Wrocław.

SUM - Словарь української мови, 1907-1909 (1996-1997), ред. Б. Грінченко, т. 1-4, Київ.

SW - Karłowicz J., Kryński A., Niedźwiedzki W., 1900-1927, Słownik języka polskiego, tzw. warszawski, t. I-VIII, Warszawa.

SXVI - Stownik polszczyzny XVI w., 1966-2012, t. I-XXXVI, Wrocław-Warszawa.

TichA - Tichoniuk B., 1988, Antroponimia południowej Białostocczyzny w XVI wieku, Opole.

TSBM - Тлумачальнь слойнік беларускай мовьл, 1977-1984, рэд. К.К. Атраховіч, т. 1-5, Мінск.

Uszak - Толковый словарь русского языка, 1935-1940, под ред. Д.Н. Ушакова, т. I-IV, Москва. 


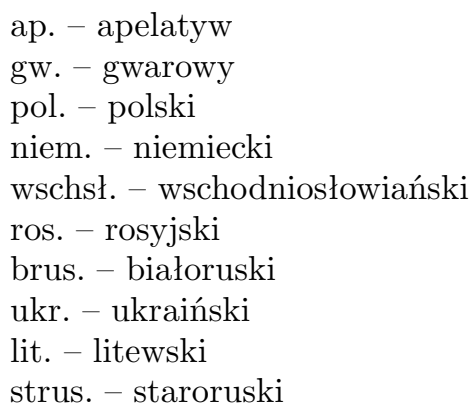

\author{
stbrus. - starobiałoruski \\ stpol. - staropolski \\ nazw. - nazwisko \\ n.os. - nazwa osobowa \\ łac. - łaciński \\ n.m. - nazwa miejscowa \\ śrwniem. - średnio-wysoko-niemiecki \\ śrdniem. - średnio-dolno-niemiecki \\ wschśrniem. - wschodnio-środkowo-niemiecki
}

\section{Literatura}

Beider A., 2008, A Dictionary of Jewish Surnames from the Russian Empire, vol. 1-2, Bergenfield, NJ.

Bubak J., 1986, Proces ksztattowania się polskiego nazwiska mieszczańskiego i chłopskiego, Kraków.

Cieślikowa A., 1990, Staropolskie odapelatywne nazwy osobowe. Proces onimizacji, Wrocław-Warszawa-Kraków.

Citko L., 2001, Nazewnictwo osobowe pólnocnego Podlasia w XVI w., Białystok.

Citko L., Dacewicz L., 1996, Typy strukturalne antroponimów w XVI-wiecznym województwie podlaskim, [w:] Antroponimia słowiańska. Materiały z IX Ogólnopolskiej Konferencji Onomastycznej, „Prace Onomastyczne” 35, pod red. E. Wolnicz-Pawłowskiej, J. Dumy, Warszawa, s. 83-91.

Czopek-Kopciuch B., 2004, Nazwiska polskie w Zagłębiu Ruhry, Kraków.

Dacewicz L., 1993, Kształtowanie sie osobowych nazw odzawodowych w dawnym województwie podlaskim (XVI-XVII w.), „Studia Podlaskie” IV, s. 93-99.

Dacewicz L., 2014, Historia nazwisk na kresach północno-wschodnich Rzeczypospolitej (XVI-XVIII w.), Białystok.

Kaleta Z., 1998, Nazwisko w kulturze polskiej, Warszawa.

Kreja B., 1998, Ksiega nazwisk ziemi gdańskiej, Gdańsk.

Kuć J., 2004, Odzawodowe nazwy osobowe w XVIII-wiecznych ksiegach parafialnych z Mokobód, [w:] Polszczyzna Mazowsza i Podlasia. Część VIII. Antroponimia

i toponimia Mazowsza i Podlasia, pod red. H. Sędziak, Łomża, s. 103-113.

Lech D., 2003, Nazwiska odapelatywne a kultura regionu, [w:] Metodologia badań onomastycznych, pod red. M. Biolik, Olsztyn, s. 217-230.

Raszewska-Klimas A., 2018, Wieloznaczność nazwisk Polaków, Łódź.

Rudnicka-Fira E., 2003, Nazwiska odzawodowe krakowian w średniopolszczyźnie (perspektywa kulturowa), [w:] Metodologia badań onomastycznych, pod red. M. Biolik, Olsztyn, s. 205-216.

Rudnicka-Fira E., 2004, Antroponimia Krakowa od XVI do XVIII wieku. Proces ksztaltowania się nazwiska, Katowice.

Rusek J., 1996, Dzieje nazw zawodów w jezykach słowiańskich, Warszawa. 
Rymut 1987, Apelatywa antroponimiczne $i$ ich miejsce $w$ etymologii słowiańskiej, [w:] Slawistyczne studia językoznawcze, pod red. F. Sławskiego, A. Chruścickiej, B. Marczak, Wrocław, s. 317-323.

Rymut K., 1982, Granica ili perehodnâ̂a oblast' meždu nomen appellativum $i$ nomen proprium, [w:] Proceedings of the Thirteenth International Congress of Onomastic Sciences, vol. II, Warszawa, p. 335-339. [Rymut K., 1982, Гранииа или переходная область между nотеп appellativum u nomen proprium, [w:] Proceedings of the Thirteenth International Congress of Onomastic Sciences, vol. II, Warszawa, p. 335-339.]

Sieradzki A., 2010, Stowotwórstwo nazwisk polskich doby staro- i średniopolskiej, [w:] Poznańskie Studia Polonistyczne. Seria Językoznawcza, t. 16, Poznań, s. 259-270.

Tichoniuk B., 1988, Antroponimia południowej Białostocczyzny w XVI wieku, Opole.

Wolnicz-Pawłowska E., Szulowska W., 1998, Antroponimia polska na Kresach południowo-wschodnich: XV-XIX wiek, Warszawa.

Złotkowski P., 2002, Antroponimy historyczne wsi Bujnowo na Podlasiu, „Rozprawy Slawistyczne UMCS" 19, s. 191-202.

Złotkowski P., 2015, Nazwiska, przezwiska i przydomki młynarzy i mieszkańców osad mtyńskich dawnego starostwa brańskiego na Podlasiu w XVI-XIX wieku, „Studia Białorutenistyczne” 9, s. 255-279.

Złotkowski P., 2016, Nazwiskotwórcza i modelowa funkcja formantu-ski/-cki w antroponimii szlachty i chłopów okolic Brańska na Podlasiu w XV-XIX wieku, [w:] Belaruska-pol'skiâ moǔnyâ, litaraturnyâa, gistaryčnyâ i kul'turnyâ suvâzi, pad rèd. İ.È. Bagdanovìc, M.Ì. Svìstunovaj, Belarusìka = Albaruthenica 37, Mìnsk, s. 80-90. [Złotkowski P., 2016, Nazwiskotwórcza i modelowa funkcja formantu -ski/-cki w antroponimii szlachty i chłopów okolic Brańska na Podlasiu w XV-XIX wieku, [y:] Беларуска-польскія моўньля, літаратурныля, гістарычныл $і$ культурныля сувязі, пад рэд. І.Э. Багдановіч, M.І. Свістуновай, Беларусіка = Albaruthenica 37, Мінск, с. 80-90.]

Złotkowski P., 2017, Antroponimia historyczna mieszczan i chłopów Brańska i okolic $w$ ujęciu statycznym $i$ dynamicznym, Lublin.

Bìryla M.V., 1966, Belaruskâ̂a antrapanimiâ. Ulasnyâ imëny, imëny-mânuški, imëny pa bac'ku, prozviščy, Mìnsk. [Бірыла М.В., 1966, Беларуская антрапанімія. Уласнья імёнь, імёнь-мянушкі, імёнь па бачьку, прозвішчь, Мінск.]

Bučko G., 2010, Suspil'no-gospodars'ki vidnosini v Galičini ta vidapelâtivni prizviŝa Bojkivŝini, [w:] Nazwy własne a spoteczeństwo, pod red. R. Łobodzińskiej, Łask, s. 221-230. [Бучко Г., 2010, Суспільно-господарські відносини в Галичині та відапелятивні прізвища Бойківщини, [w:] Nazwy własne a spoŁeczeństwo, pod red. R. Łobodzińskiej, Łask, s. 221-230.]

Gužva F.K., 1978, Sovremennyj russkij literaturnyj âzyk. Čast' I, Kiev. [Гужва Ф.К., 1978, Современный русский литературный язык. Часть I, Киев.] 


\title{
CONTEMPORARY SURNAMES OF PODLASIE DERIVED FROM THE NAMES OF PROFESSIONS, COURTESY TITLES AND PROFESSIONAL TITLES
}

\author{
ABSTRACT
}

Key words: linguistics, onomastics, anthroponymy, surnames, trade names

The paper presents contemporary surnames of Podlasie derived from the names of professions, courtesy titles, held offices and performed functions. Several groups of anthroponyms were identified through etymological analysis of the gathered material, primarily focused on the semantics of word roots. Contemporary surnames were formed from the following categories of words associated with: 1) crafts (Bondar, Kowalczuk), 2) agriculture, forestry and animal production (Fiszer, Pastuszak), 3) food preparation (Kucharczuk, Mielczarek), 4) trade (Budnik, Salnikow), 5) protection of objects and facilities (Leśnik, Pasiecznik), 6) mansion service (Dworańczyk, Pachołek), 7) music (Fidler, Grajko), 8) occasional functions (Drużba, Krzyżak), 9) religion (Kirchner, Monachowicz), 10) military service (Atamańczyk, Janczar), 11) public offices (Rejent, Tywonek), 12) social status (Dziedzic, Ofman), 13) others (Godun, Stangryciuk). Some surnames (e.g. Budnik, Hajduk, Pachołek) were allocated to more than one category because of their polysemous lexemes. From a linguistic point of view the analysed surnames come from Polish (Cieśla, Krawiec), East Slavic (Czebotariow, Monach), German (Rezler, Sznajderuk) or Baltic words (Dojlida). In terms of word formation, most surnames are the equivalents of common names (Kołodziej, Ogrodnik), although there are also derivative surnames with suffixes (Korolko, Szwajdych), some representing the patronymic model (Majstrowicz, Tokarzewicz; Puszkaruk, Szklaruk) or having genetically possessive suffixes (Kniaziew, Winnikow). 